\title{
Learning to identify the benign thoracic manifestations of asbestosis from a single patient
}

\author{
Zahi Nachef, Pichapong Tunsupon, M Jeffery Mador
}

Department of Medicine, Division of Pulmonary, Critical Care and Sleep Medicine, University at Buffalo State University of New York School of Medicine and Biomedical Sciences, Buffalo, New York, USA

\section{Correspondence to Dr Pichapong Tunsupon ptunsupon@gmail.com}

Accepted 30 May 2016
CrossMark

To cite: Nachef $Z$, Tunsupon P, Mador MJ. BMJ Case Rep Published online: [please include Day Month Year] doi:10.1136/bcr-2016216107

\section{DESCRIPTION}

A 76-year-old man was referred for evaluation of an asymptomatic left lower lobe mass. He had a history of asbestos exposure, as he worked aboard a navy ship in the 1950s for 5 years. He carried a 60 pack-year smoking history but had quit smoking 30 years earlier. Cardiopulmonary examination was unremarkable. Pulmonary function test (PFT) demonstrated a restrictive pattern with normal diffusion capacity. CT of the chest revealed five benign findings of pleural asbestosis (figures 1-3).

Benign asbestos pleural effusion is an early manifestation of pleural asbestosis occurring after a few decades of asbestos exposure (figure 1). The pleural effusion is generally minimal and unilateral. Thoracentesis profile sometimes reveals a haemorrhagic exudate. Pleural plaques are fibrous tissues originating from the parietal pleura classically distributed in the lateral chest wall between the sixth and ninth ribs, sparing apices and costophrenic angles. It typically does not cause pulmonary symptoms nor does it affect the PFT. Calcification of the pleural plaques occurs in long-lasting mature plaques. Involvement of the diaphragmatic pleura is pathognomonic for asbestos plaques (figures 1-2). In contrast, pleural thickening secondary to chronic inflammation predominantly involves the visceral pleura, which contributes to a restrictive pattern and impaired ventilation. Pleural thickening does not calcify and can blunt the costophrenic angles. ${ }^{1}$ Rounded atelectasis is an atelectatic area of the lung adjacent to the pleural thickening and is strongly associated with asbestos exposure (figure 3). It occurs as a consequence of the pleural thickening

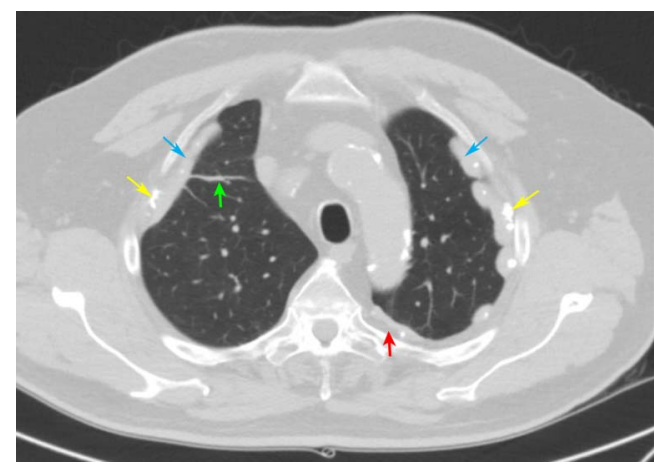

Figure $1 \mathrm{CT}$ of the chest demonstrates bilateral calcified pleural plaques (yellow arrow), pleural thickening (light-blue arrow) with trace left pleural effusion (red arrow), and the right upper lobe fibrotic band (green arrow).

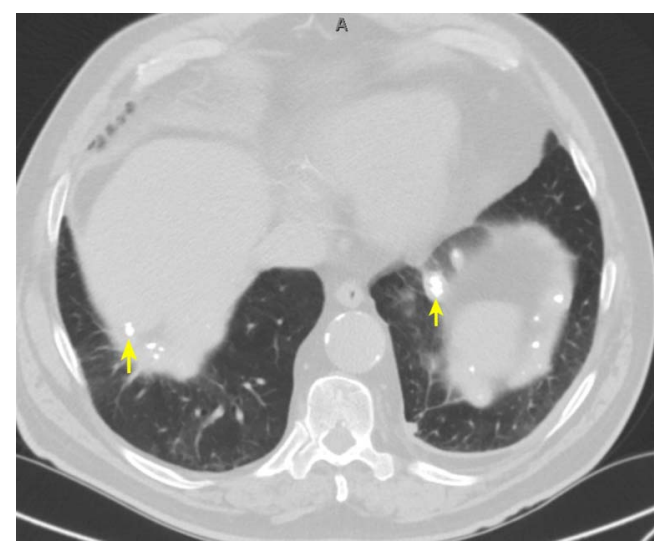

Figure 2 CT of the chest demonstrates discrete areas of calcified diaphragmatic pleura bilaterally (yellow arrow), which is virtually pathognomonic for asbestos plaque.

and can involve any lobe. ${ }^{2}$ Round atelectasis sometimes spontaneously resolves. It is metabolically inactive on PET-CT imaging. ${ }^{1}$ A fibrotic band is a thickening of the visceral pleura resulting in a pleural-parenchymal fibrous band radiating from the pleura (figure 1). These bands should not be confused with interstitial lung disease. ${ }^{1}$

Radiologic follow-up of our patient over the course of 2 years revealed the stability of these findings confirming the benign aetiology. Thus, he required no further investigations.

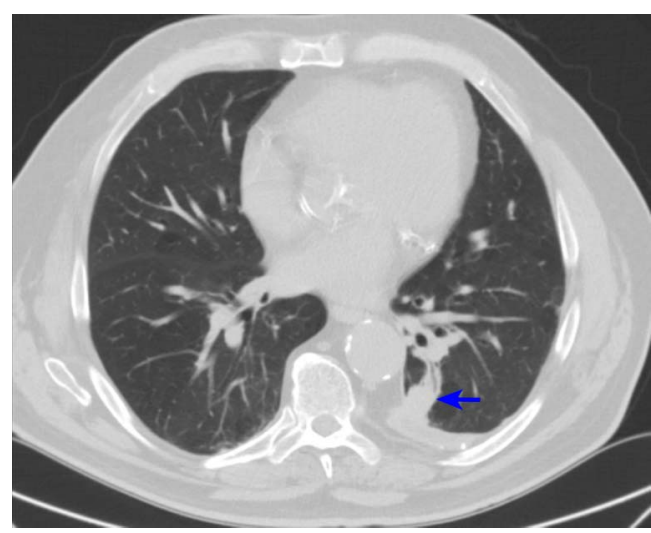

Figure $3 \mathrm{CT}$ of the chest demonstrates a rounded opacity in the medial segment of the left lower lobe abutting the pleura with extensions towards the left hilum, measuring $\sim 3.4 \times 2.3 \mathrm{~cm}$ (dark blue arrow). This lesion is suggestive of rounded atelectasis with the characteristic "comet tail" sign, which consists of the bronchovascular bundle arising from the hilum and getting pulled towards the lesion as the lung collapses. ${ }^{3}$ 


\section{Learning points}

- Physicians should be cognisant of the patterns and benign nature of pleural conditions associated with asbestos exposure.

- The common radiographic manifestations of pleural asbestosis are pleural plaque with or without calcification, pleural thickening and round atelectasis. Other pleural diseases associated with asbestos exposure include benign pleural effusion and fibrotic bands.

- The evidence suggests that pleural plaques are not associated with malignant transformation. However, a history of asbestos exposure is the major risk factor for malignant mesothelioma and is a significant risk factor for bronchogenic alveolar carcinoma especially with a history of cigarette smoking.
Acknowledgements ZN, PT and MJM prepared the manuscript or revised it critically for important intellectual content and approved the final version before submission to the journal.

Contributors ZN, PT and MJM prepared the manuscript or revised it critically for important intellectual content and approved the final version before submission to the journal.

Competing interests None declared.

Patient consent Obtained.

Provenance and peer review Not commissioned; externally peer reviewed.

\section{REFERENCES}

1 Norbet C, Joseph A, Rossi SS, et al. Asbestos-related lung disease: a pictorial review. Curr Probl Diagn Radiol 2015;44:371-82.

2 McHugh K, Blaquiere RM. CT features of rounded atelectasis. AJR Am J Roentgenol 1989;153:257-60.

3 Szydlowski GW, Cohn HE, Steiner RM, et al. Rounded atelectasis: a pulmonary pseudotumor. Ann Thorac Surg 1992;53:817-21.

Copyright 2016 BMJ Publishing Group. All rights reserved. For permission to reuse any of this content visit

http://group.bmj.com/group/rights-licensing/permissions.

BMJ Case Report Fellows may re-use this article for personal use and teaching without any further permission.

Become a Fellow of BMJ Case Reports today and you can:

- Submit as many cases as you like

- Enjoy fast sympathetic peer review and rapid publication of accepted articles

- Access all the published articles

- Re-use any of the published material for personal use and teaching without further permission

For information on Institutional Fellowships contact consortiasales@bmjgroup.com

Visit casereports.bmj.com for more articles like this and to become a Fellow 